\title{
A mini review on role of brcal in breast cancer
}

Farwa Jabbir ${ }^{1}$, Muhammad $\operatorname{Irfan}^{1}$, Ghulam Mustafa ${ }^{2}$ and Hafiz Ishfaq $\mathrm{Ahmad}^{3,4^{*}}$

1. Department of Biotechnology, University of Sargodha-Pakistan

2. Department of Biochemistry, GC University, Faisalabad-Pakistan

3. Guangdong Key Laboratory of Animal Conservation and Resource Utilization, Guangdong Public Laboratory of

Wild Animal Conservation and Utilization, Guangdong Institute of Applied Biological Resources, Guangzhou, Guangdong-China

4. Department of Animal Breeding and Genetics, University of Veterinary and Animal Sciences, Ravi campus, Pattoki, Pakistan

*Corresponding author's email: hafizishfaq93@outlok.com

Citation

Farwa Jabbir, Muhammad Irfan, Ghulam Mustafa and Hafiz Ishfaq Ahmad. A mini review on role of brca1 in breast cancer. Pure and Applied Biology. Vol. 9, Issue 1, pp650-663. http://dx.doi.org/10.19045/bspab.2020.90071

\begin{tabular}{llll}
\hline \hline Received: 26/09/2019 & Revised: 27/11/2019 & Accepted: 05/12/2019 & Online First: 20/12/2019 \\
\hline \hline
\end{tabular}

\section{Abstract}

Breast cancer development across the societies is caused by several effects including environmental, genetic, and acquired. Among all of these genetics, like influencing genes that are involved in the development of this disease among families with a history of breast cancer in several generations, should be considered more. The maximum rate of breast cancer has been seen in Pakistan of any Asian public. Around 1,500 years B.C breast cancer precede in olden times. Primitive Traditional assembly of societies more than 3,500 years ago, were the initial to article the disease. BRCA2 and BRCA1 are the two foremost experience genetic material tangled in heritable breast cancer. The genetic factor conversions are accountable for a big share of $B R C A 1$ and $B R C A 2$. Furthermore, $B R C A$ mutations were found in people with and without family history. BRCAl gene programs for a tumor suppressor protein that helps in repairing of DNA that has become destabilized to ensure the constancy of genetic material in cells and further in transcription and recombination.. Women with a BRCA amendment must be absorbed to the benefit of breastfeeding in dealings for tumbling breast cancer exposure. In this review the role of brcal in breast cancer has been studied in detail.

Keywords: Breasrt cancer; BRCA1; BRCA2

\section{Introduction}

Cancer, also called malevolence, is an irregular progression of cells. The query of "what reasons tumor" has fascinated Individuals for conventions [1]. In 1950, the World Health Organization supported a world symposium, and therefore participants were interested in the histrionic dissimilarities within the categories of cancer routine, in numerous areas of the world [2]. The major reason for $15 \%$ of all cancer deceases and $25 \%$ of all cancer cases in Women is breast cancer [3]. There are 200 diverse types of cancers and a few of that are anal cancer, adeno breast cancer, thyroid cancer, colon cancer, liver cancer, leukemia, kidney cancer, skin cancer, colorectal cancer, ovarian and breast cancer [4]. For the Pakistani population an insight into the frequency data within the year 2012 interpretation of a BRCA1 and BRCA2 catalogue was emphasized [5], for breast 
cancer the annual Age-Standardized Incidence Rate (ASIR) raised at: 43.3/100,000 Women at a world level and at 50.3/100,000 in Pakistan [6]. The most prevailing cancer within the biosphere is breast cancer, BRCA1 was 1st known as a nuclear phosphoprotein [7]. The genes transformations are accountable for a big share of breast cancer BRCA1 and BRCA2. $B R C A$ mutations were found in people with and while not family history [8].

\section{Cancer epidemiology}

By the time of Greek physicians within the fourth century B.C., many varieties of progressions were clinically recognized and demarcated. Cancer because of fault in genes or could also be the carcinogens or result of genetic subjectivity that's transmissible from the family [9]. Scientists stated within the journal scientific reports, from the PhysicalSciences-oncology centers USA, that malicious cells are a lot of smaller than nonmalignant ones [10]. Cancer cells will pass more simply as compared to the opposite cells, through smaller gaps [11]. Among Pakistan, Women have the maximum rates of ovarian and breast cancer in the Asian states [12] with breast cancer being the prime communal and ovarian the third most typical cyst and therefore it's the most conventional cancer of conceptive basis in Pakistan [13]. A nine-year study presented that in Pakistan breast cancer accounted for $38.2 \%$ of total cancer cases and it was the leading common cancer in females, then at a triennial concern cancer establishing in Karachi, at rates virtually maximum in Asia and ovarian cancer with a percentage of 4.9 overall [14].

\section{Breast cancer and its types}

Nowadays, breast cancer is the supreme examined serious cancer often in women and therefore it is the foremost reason behind tumor decease amongst women [15]. Since last 20 years, studies associated with the breast cancer had run to a surprising progress in our consideration of the ailment, leading to a lot of economic and fewer deadly treatments [16]. Improved public consciousness and improved screening have headed to the previous designation at phases agreeable to broad clinical operation and healing treatments [17]. Subsequently, existence proportions for breast tumor have amended ominously, suggestively in young women. The content accounted the kinds, reasons, medical indications and numerous method each non- drug (such as surgical procedure and radioactivity) and medicine dealing of breast cancer [18]. The fears fluctuated in stages that have traditionally been connected to the disease due to the interpretation that cancer cannot be cured. It will find colorectal, cervical and breast cancer at an early curable stage. Why cancer cell flat tire scientists described in nature communications [19].

Different approaches like introns and the other (fifty and thirty) untranslated regions are commencing to use that sequence as noncoding regions [20]. Many cancers develop because of heritable dysregulation and change the cellular pathways that consequence in gene mutations. Breast cancer survival rate hasn't created a big improvement though there are some enhancements on the designation and in the treatment and therefore it's one among the foremost normally diagnosed cancers [21]. Early menarche, late age at the primary point in gestation period late age at climacteric, 3 or fewer mature gestations and optimistic history of breast cancer have a considerable bier exposure of breast cancer within the family [22]. Factors systematically found to extend breast cancer risk are Null parity, initially no breastfeeding, sentient birth at an earlier age and older age. The most prevailing cancer among women worldwide is breast cancer [23] and a high quantitative relation of pregnancies which were incomplete and at considerably amplified danger of breast cancer [24]. In keeping with 
WHO facts, the individuals analyzed with breast cancer each year are relatively 1.2 million worldwide [25]. Pakistan has the very best age-standardized rate at 69 per 100,000 of breast cancer shown by the population primarily based cancer register information from South Asia [26]. 141 cases identified throughout a 10-year period of male breast carcinoma were studied by Jamal (1992- 2001), fitting to northern Pakistan.
Types of breast cancer a) Invasive breast cancer b) Infiltrating carcinoma (ILC) and c) there are some less occurring carcinoma like medullary carcinoma, mutinous carcinoma, tubular carcinoma and inflammatory breast cancer (Figure 1) [27]. The supervision of breast cancer rests on a variety of things, together with the phase of the tumor [28]. It's usually treated with surgery, which can be followed by irradiations.

\section{a) Infiltrating (70\%) Ductal, Lobular}

b) Insitu (30\%) DCIS, LCIS

c) Other Inflammatory, tubular, medullary, pregnancy induced

Figure 1. Types of breast cancer

There are three types of breast cancer as shown in the figure 1 in which first type is invasive type which includes $\mathbf{7 0 \%}$ ductal and lobular carcinoma and in second type is Insitu which includes $30 \%$ ductal and lobular carcinoma then in third type other inflammatory, medullary pregnancy induced carcinoma is included

\section{Causes of breast cancer}

Earlier account of breast cancer. A woman who has ought to breast cancer has associate inflated peril of obtaining breast malignant cells within the different breast [29]. Significant case history: If many fellows of deceased people have explicit kinds of tumor, patient might have associate improved peril of evolving breast cancer [30]. Following are the other causes of breast cancer. 1) Genetic causes 2) Hormonal causes 3) Environmental causes (Figure 2).

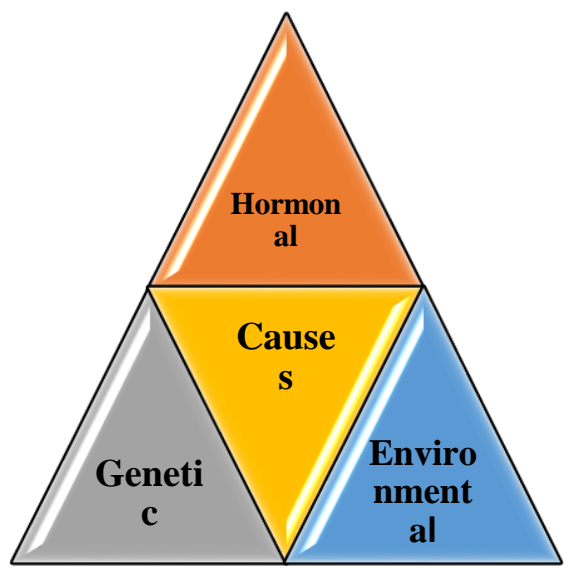

Figure 2. Reasons of breast malignancy. Here are three types of causes which are responsible for breast cancer first are genetic causes secondly there are hormonal causes and thirdly environmental causes as shown in this figure 2 


\section{Signs and symptoms}

The definitive indication for breast cancer could be a swelling start within the breast or cavity. Doing regular breast self-exam (BSE) could be a good tactic to be aware of the breasts' consistency, cyclic fluctuations, mass, and covering the state [31]. The final warning options of breast tumor are like inflammation or tumor (mass) within the breast, puffiness within the cavity (lymph nodes), mammilla release (clear or bloody), pain within the mammilla, reversed (retracted) mammilla, flaking or faveolated skin on mammilla, obstinate soreness of the breast, and strange (Figure 3) [32].

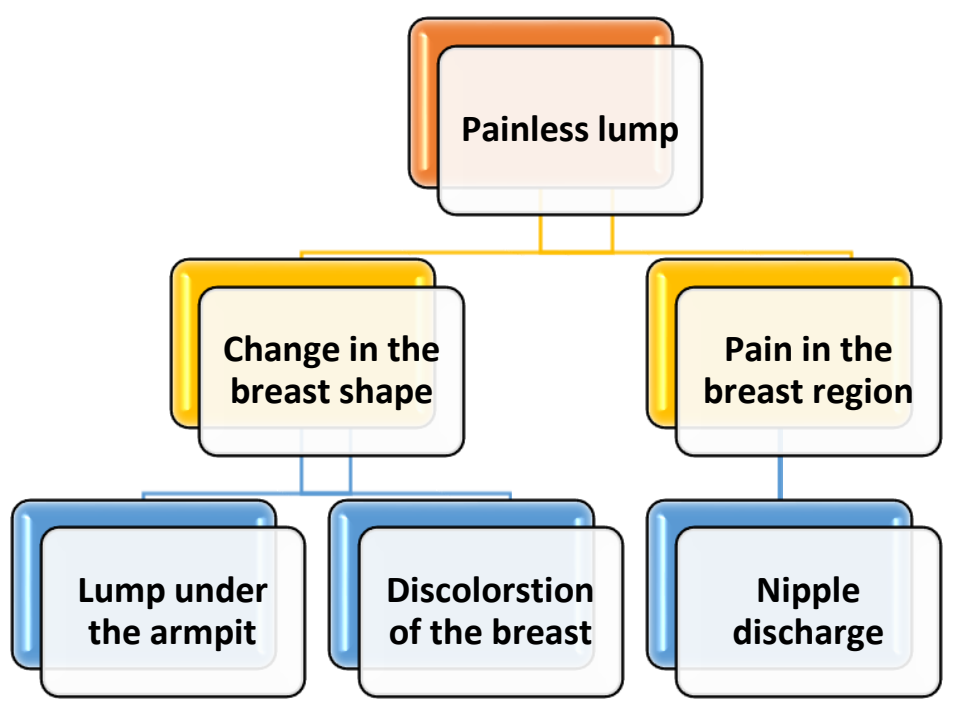

Figure 3. Symptoms of Breast carcinoma

Here are many symptoms for breast cancer some of which are shown in the figure 3 as change in the breast shape, lump under the armpit, discoloration of the breast, pain in the breast region etc

\section{Stages of breast cancer}

When the tumor is detected, a phase is appointed there, supported on however progressive it's. The phase aids doctors to verify the foremost applicable treatment and therefore the prediction [33]. Phases of breast cancer could also be delineated usually as lotus or hostile to the major five phases of breast cancer phase 0 is the phase of abnormal cells first phase is of early stage then next phase is of localized cells third phase is of regional spread and phase five is of distant spread as shown in the table 1 [34].

Table 1. Different Phases of Breast carcinoma [35-37]

\begin{tabular}{|c|c|c|}
\hline 0 phase & Abnormal cells & Abnormal cells are present but have not spread to nearby tissues \\
\hline 1st phase & Early stage & Cancer has spread to other tissues \\
\hline 2nd phase & Localized & $\begin{array}{c}\text { Tumor is between 20-50mm and some lymph nodes are involved or } \\
\text { a tumor larger than 50mm with lymph nodes involved }\end{array}$ \\
\hline 4th phase & $\begin{array}{c}\text { Regional } \\
\text { spread }\end{array}$ & $\begin{array}{c}\text { Tumor is larger than 50mm, with more lymph nodes involved } \\
\text { across a wide region. In some cases, there is no tumor present at all. } \\
\text { Cancer may have spread to skin or chest wall. }\end{array}$ \\
\hline
\end{tabular}




\section{$B R C A 1$ and its importance}

BRCA1 macromolecule weigh up as a growth suppressor; in healthy cells, it functions to take care of correct genomic repair and cellular partition, however transmissible alterations within the BRCAl factor alteres varieties of the macromolecule that recommend to enlargement of breast and ovarian cancer [38, 39]. BRCAl factor was found on chr17q, accompanying any changes or alterations during this factor will cause an amended exposure of developing breast, ovarian, and prostrate breast cancer [40] BRCA1 and BRCA2 are the breast tumor accountability genetic factors whose germline alterations predispose transporters principally to breast cancer however the same to numerous different growths [41]. Maximum growths coupled to breast tumor susceptibleness macromolecule class one (BRCA1) and breast cancer susceptibleness macromolecule class two (BRCA2) prevail impairment of heterozygosity therefore these genetic factors are named as growth suppressors [42]. On the idea of their battered part in keeping the genomic reliability, they are categorized as "verger of the order". Though there are lots to try to expose the exact organic part of the $B R C A 1$ and $B R C A 2$ factor yields; close by information verifying each of them as transcriptional management protein DNA overhaul $[39,43]$.

In response to cellular stress, $B R C A I$ and $B R C A 2$ that show an important role via the activation of DNA repair processes are two distinct growth suppressor genes [44]. People are at a bigger exposure of developing breast, ovarian, and different cancers having a mutation in these two genes. $45-80 \%$ is the lifespan risk of breast cancer among $B R C A$ mutation transporters and 45-60\% is for ovarian cancer (Table 2) [45]. Many studies have investigated prognoses among $B R C A$ mutation carriers and non-carriers [46]. Germline transformations in BRCAl and $B R C A 2$ are the foremost communal far- famed reason behind hereditary breast and ovarian cancer, and transmission for changes in these genes is wide existing to womenfolk with a robust case antiquity or early-onset breast cancer in states with directed middles [47]. Ancestral breast cancer could be a diverse sickness in which hormonal, and ecological factors can confuse risks related to BRCA1 alterations. Pakistani patients will have the benefit of selective transmission of $B R C A 1$ factor and mutation primarily based control for little and reasonable families if one (1st or $2^{\text {nd }}$-degree comparative) is affected or preliminary start ailment is superficial [48]. Women with a BRCA alteration must be directed to the benefit of breastfeeding in dealings of dropping breast cancer peril [49]. BRCA1 factor alterations source breast cancer in women with a prospect of $60 \%$ to $80 \%$ and likewise cause improved menace of ovarian cancer growth in women and prostate breast cancer in men [50]. Germ-line alterations in BRCA2 factor are seen in some $35 \%$ of families with earlyonset breast cancer in women associated cause equally an increased peril of ovarian cancer development in women and breast cancer in men [51]. Breast cancer caused by an alteration in $B R C A I$ factor incorporates a higher frequency, higher mitotic rate, and a lot of liquid body substance penetrance than irregular breast cancer [52]. Dysregulation of key genes causes incidence and development of breast cancer [53], higher understanding of the genetic changes can profit each the designation and therefore the treatment of breast cancer. The BRCAI macromolecule aids to overhaul broken DNA, and sympathetic however BRCAl becomes local so it will perform repair and whether bound mutations to sites of DNA injury [30]. This table is showing some important features of BRCA1 like gene locus, population frequency, inheritance, lifetime risk of breast cancer in females, pathological features of breast tumors and other associated tumors. 
Table 2. Important features of BRCA1 [54-56]

\begin{tabular}{|c|c|}
\hline Feature & BRCA1 \\
\hline Gene locus & Chromosome 17 \\
\hline Population frequency & 1 in 400 \\
\hline Inheritance & Increased to 1 in 50 in Ashkenazi Jews \\
\hline $\begin{array}{c}\text { Lifetime risk of breast cancer } \\
\text { (females) }\end{array}$ & $40-80 \%$ \\
\hline $\begin{array}{c}\text { Pathological features of breast } \\
\text { tumors }\end{array}$ & $\begin{array}{c}\text { Typically, high grade with lymphocytic infiltrate and pushing tumor } \\
\text { margins, ER, PR, HER-2 negative }\end{array}$ \\
\hline Lifetime risk of ovarian cancer & 40-60\% \\
\hline Other associated tumors & Pancreatic \\
\hline
\end{tabular}

\section{Prevalence}

Breast cancer is that the maximum typical cancer in women everywhere in the World with about one million new cases annually further it's a second important cause of decease amid Women [57]. In Pakistan, the leading analyzed tumor amid the women is also breast cancer, secretarial for closely one in nine feminine vexed persons. Its frequency in Pakistan is 2.5 periods over not later than flanking nations analogous to other Asian countries [58].

\section{Predisposing factors of breast cancer}

Cultural and topographical dissimilarities surrounded by the frequency of breast cancer prove the result of ecological situations and lifestyle. Medication lessons have far-famed several menace aspects for Breast Cancer [59]. These non-genetic factors include: early climacteric, alcohol and tobacco, contact to radiation, fatness, condensed corporeal activity, expansion, inactive lifestyle, high fat diet, everyday impulsive lapses, lack of breastfeeding, internal oozing replacement medical irradiation, aging: topographical location, socio-economic situations, replica events, exogenous hormones, breast density, and case history of breast cancer or different cancers [60].

\section{Analysis of breast cancer}

Analysis of breast cancer can be done by following methods 1. Mammography 2 . Magnetic resonance imaging (MRI) 3.
Molecular breast imaging (MBI) 4. Breast Biopsy [61].

\section{Screening}

For many kinds of breast malignant cells, the probability of lymph gland attack and deteriorating growth slash will surge as lump mass will rise [62], after indigent long existence. Breast tumor broadcast is brought over organized population-based transmission plans or by devious instance discovery. The time-serving method happens once a broadcast check is accessible to a person while not signals of breast malignant cells after they surviving to their strength overhaul professional person for distinct motives [63].

\section{Fertility preservation and role of breast cancer}

In many young women analyzed with breast cancer this truth has been reportable in varied studies that fertility conservation is a vital concern [64]. Finally, BRCA mutation carriers, either healthy or previously identified with breast cancer, also are able of completing gestation in spite of their valueadded complications mainly a better growth assertiveness and a lower ovarian spare [65]. A current Swedish study reportable that solely $48 \%$ of young feminine toughies of various cancers were enlightened regarding the threats to productiveness, merely Bastille Day was progressive about fertility protection methods, and only $2 \%$ used these methods [66]. 


\section{Risk of pregnancy and lactation after breast cancer}

The warning for breast cancer starts with gestation and lactation within the general masses. There is proof that means a fleeting surge in breast cancer within the four years following a gestation. However, different authors failed to understand this relation [67]. Current studies have reportable that $40-50 \%$ of womenfolk with former past of breast cancer might need to possess a succeeding gestation, however solely $4-7 \%$ achieve to superiority [68]. Estrogens are far-famed to play a task in breast cancer-causing agents and are improved throughout gestation. These reservations have subsidized to surgeons to direct afflicted persons against gestation. Some studies reportable abortion rates concerning as 30\% [69]. Though, recent on the market information don't exclusively report the associate adverse result of a succeeding gestation on breast cancer outcome however equally a possible favorable impact on prediction [70].

\section{Breast cancer risk}

The early approximations of ordinary accumulative breast cancer peril to age 70 years for feminine alteration transporters were 85 looking onward to $B R C A 1$ and 84 looking onward to BRCA2 [71]. Since these assessments were from studies of very great multiple-case families with a least of four members of the family with ovarian or breast cancer [39]. The motive subject is genetic susceptibleness in Women or ecological issues that are nonetheless to be watched hooked on [28]. Among all attainable danger aspects, the amendment within the genetic data is the most common issue. In unhealthy people of Pakistan occurrence of BRCAl or $B R C A 2$ mutations [72] are initiated distinctively to Pakistan. This risk of breast cancer increases with the age as the age increases like more risk is in females of age more than sixty years and the chance of mutated BRCA1 is $55-65 \%$ by the age of seventy as shown in the figure 4 [73].

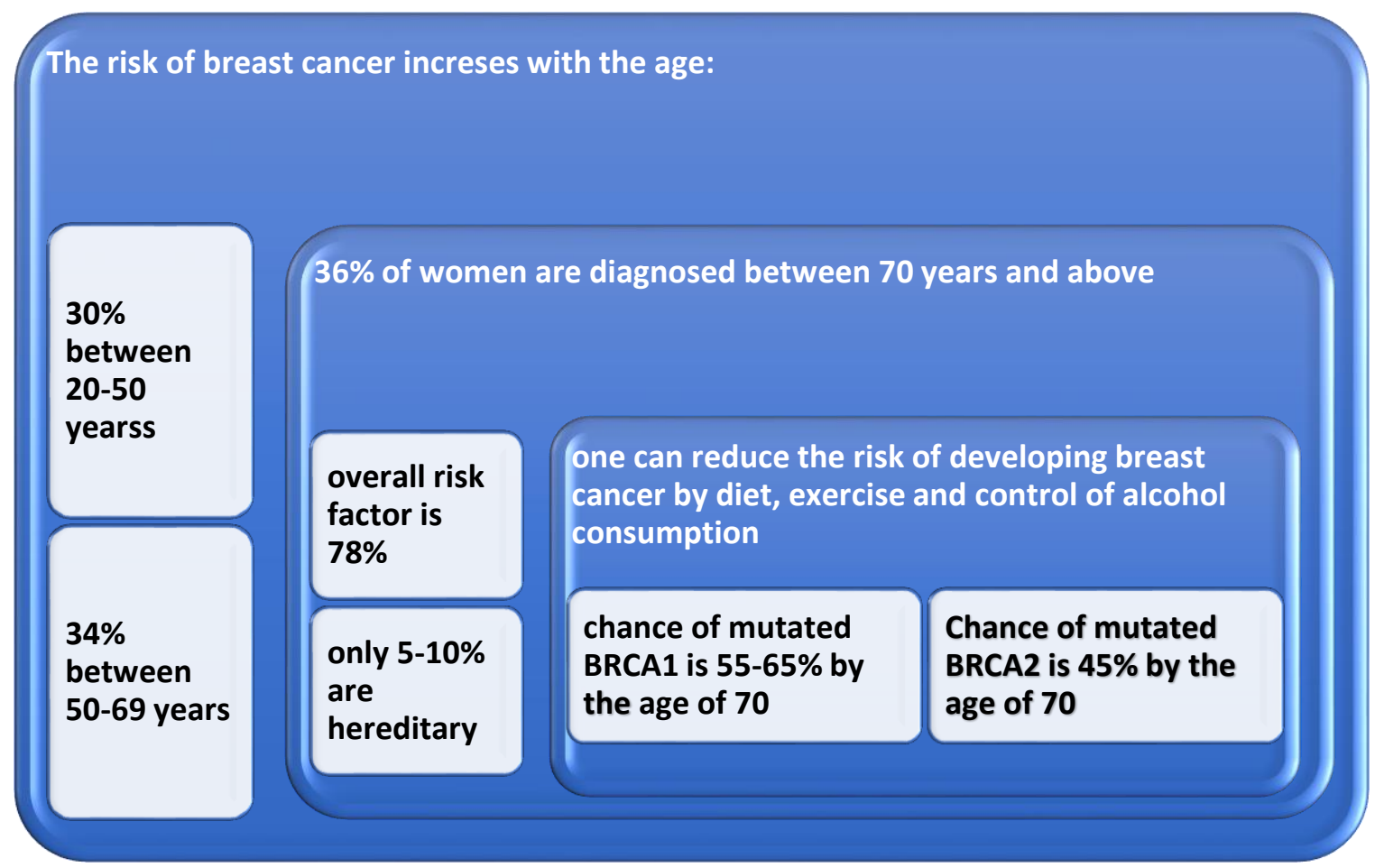

Figure 4. Increase in breast cancer risk with age 


\section{Treatment}

It's still troublesome to effectively treat breast cancer because it could be a heterogeneous disease [74]. For breast cancer, we regularly depend upon different types of treatments together with internal secretion, medical care and irradiation [75]. On a lot of affirmative letters, the advances completed within the cure of breast cancer over the earlier 20-30 years seem customary to prevail, lightemitting diode by the panorama of higher craft remedies to individual afflicted persons through molecular empathy [76].

Treatment methods Patents and analysis papers exploration titles for breast cancer by means of new skills which are graphed for the previous fifteen years [39]. For improving the therapeutic worth of anti-tumor medication numerous nanocarriers are introduced,

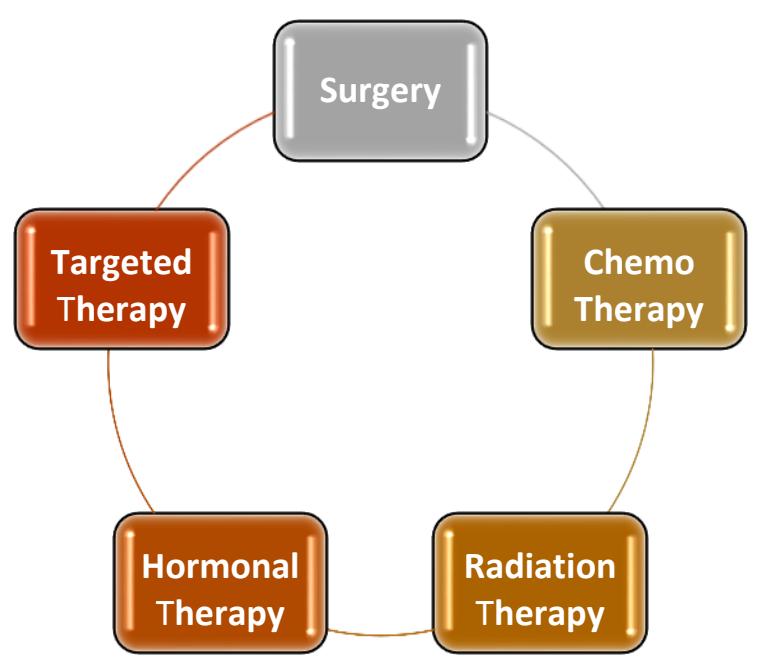

Figure 5. Treatment tactics for breast cancer

\section{Role of $B R C A I$}

BRCAl appearance is very significant in DNA healing, initiation of cell-cycle checkpoints, protection of body control. Certainly, most breast malignancies that are linked to a $B R C A 1$ alteration, whether or not irregular or genetic, have a radical-like triplecounter structure [81], fifteen Lumps related to the BRCA2 alteration have the supply of together with liposomes, compound micelles, nanoparticles, quantum dots and dendrimers. Treatments for breast and ovarian cancers might render a woman unproductive [77]. This understanding, like the modified key factor profiles and biological processes, a lot of concerning the molecular changes throughout the breast cancer development, can significantly improve the description and treatment of breast cancer [78]. Cancer cells that will not be perceived throughout surgery is slew by radioactivity to cut back the chance of native repetition of cancer [79], RT could be a method for the high level of radiations which are directly exposed to cancer cells [80]. The Treatment of Breast cancer can be done by surgery, chemotherapy, radiation therapy, hormonal therapy and targeted therapy as shown in figure 5. 
trail of heredity defense. However, the work of these 2 proteins completely varied footsteps within the DNA impairment response and in DNA overhaul. BRCAI could be a pleiotropic DDR protein that purposes in each like initiation and DNA healing, while $B R C A 2$ could be a negotiator of the central tool of homologous recombination [83]. The relations between the two proteins aren't well implicit, however, they need to persist to elucidate the marked resemblance of human cancer susceptibleness that ascends with germline alterations in these genes. As mentioned here, the proteins add the concert to armor the assembling from double-strand DNA injury throughout DNA duplication [84]. Along with other proteins complex in DNA damage response; both $B R C A 1$ and $B R C A 2$ are in molecular foci through s-phase or upon the molecular action of the cells with DNA deleterious agents [85].

\section{Conclusion}

Breast cancer is the major reason of death in women universally and its ratio is increasing very swiftly. BRCAl is involved in DNA damage and cell cycle checkpoint which contributes to breast cancer. Being an undeveloped country, we are lacking the treatments of breast cancer, however, the advance research is ongoing to find the cure for this disease.

\section{Authors' contributions}

Conceived and designed the experiments: M Irfan \& $G$ Mustafa, Performed the experiments: F Jabbir \& HI Ahmad, Analyzed the data: F Jabbir \& HI Ahmad, Contributed materials/ analysis/ tools: M Irfan, G Mustafa, F Jabbir \& HI Ahmad, Wrote the paper: Farwa jabbir \& Hafiz Ishfaq Ahmad.

\section{Acknowledgement}

Authors are thankful to anonymous reviewers for critical review of manuscript.

\section{References}

1. Liu CC, Yang H, Zhang LL, Zhang Q, Chen B \& Wang Y (2014). Biotoxins for cancer therapy. Asian Pac J Cancer P 15(12): 4753-4758.

2. Davis CD \& Ross S (2019). Diet and cancer prevention. Am J Lifestyle Med 409.

3. Stewart B \& Wild CP (2014). World Cancer Rep 2014.

4. Siegel RL, Miller KD \& Jemal A (2019). Cancer statistics, 2019. CA: CA J Clin 69(1) 7-34.

5. Farooq A, Naveed AK, Azeem Z \& Ahmad T (2011). Breast and ovarian cancer risk due to prevalence of BRCA1 and BRCA2 variants in Pakistani population: a Pakistani database report. $J$ Oncol 2011.

6. Badar F, Faruqui Z, Uddin N \& Trevan E (2011). Management of breast lesions by breast physicians in a heavily populated South Asian developing country. Asian Pac J Cancer P 12(3), 827-832.

7. Henderson BR (2012). The BRCA1 breast cancer suppressor: regulation of transport, dynamics, and function at multiple subcellular locations. Scientifica, 2012.

8. Ibrahim SS, Hafez EE, \& Hashishe MM (2010). Presymptomatic breast cancer in Egypt: role of BRCA1 and BRCA2 tumor suppressor genes mutations detection. J Exp Clin Canc Res 29(1): 82.

9. Kane $\mathrm{G}$, Petrosyan V \& Ameerally $\mathrm{P}$ (2019). Oral Cancer Treatment Through the Ages. J Oral Maxil Surg (Part 1).

10. Network TP SOC, Agus DB, Alexander JF, Arap W, Ashili S, Aslan JE, Bonneau R (2013). A physical sciences network characterization of non-tumorigenic and metastatic cells. Sci Rep 3 (1449).

11. Agus DB, Alexander JF, Arap W, Ashili S, Aslan JE, Austin RH \& Chen WC (2013). A physical sciences network 
characterization of non-tumorigenic and metastatic cells. Sci Rep 3.

12. Rashid MU, Zaidi A, Torres D, Sultan F, Benner A, Naqvi B \& Narod S (2006). Prevalence of BRCA1 and BRCA2 mutations in Pakistani breast and ovarian cancer patients. Int J Cancer 119(12): 2832-2839.

13. Bhurgri Y (2004). Karachi cancer registry data--implications for the national cancer control program of pakistan. Asian Pac J Cancer P 5(1): 7782.

14. Hanif M, Zaidi P, Kamal S \& Hameed A (2009). Institution-based cancer incidence in a local population in Pakistan: nine year data analysis. Asian Pac J Cancer P 10(2): 227-230.

15. Tsoucalas G, Karamanou M, Sgantzos M, Deligeoroglou E \& Androutsos G (2015). Uterine cancer in the writings of ancient Greek physicians. $J$ BUON 20(5): 1382-1385.

16. Marx, V. (2013). Tracking metastasis and tricking cancer. Sci Rep

17. David AR \& Zimmerman MR (2010). Cancer: an old disease, a new disease or something in between? Nat Rev Cancer 10(10): 728.

18. Sharma GN, Dave R, Sanadya J, Sharma P \& Sharma K (2010). Various types and management of breast cancer: An overview. Journal of advanced pharmaceutical technology \& research, 1(2): 109.

19. Reticker-Flynn NE, Malta DFB, Winslow MM, Lamar JM, Xu M, Underhill GH \& Bhatia SN (2012). A combinatorial extracellular matrix platform identifies cell-extracellular matrix interactions that correlate with metastasis. Nature communications, 3, 1122.

20. Walsh T, Lee MK, Casadei S., Thornton AM, Stray SM, Pennil C \& King MC (2010). Detection of inherited mutations for breast and ovarian cancer using genomic capture and massively parallel sequencing. Proc Natl Acad Sci USA 107(28): 12629-12633.

21. Zhang S, Royer R, Li S, McLaughlin JR, Rosen B, Risch HA \& Narod SA (2011). Frequencies of BRCA1 and BRCA2 mutations among 1,342 unselected patients with invasive ovarian cancer. Gynecol oncol 121(2): 353-357.

22. Li M, Zhang J, Ouyang T, Li J, Wang T, Fan Z \& Xie Y (2016). Incidence of BRCA1 somatic mutations and response to neoadjuvant chemotherapy in Chinese women with triple-negative breast cancer. Gene, 584(1): 26-30.

23. Rabia T, Sadia H \& Fatima A (2013). Molecular stress or geography risk factors leading to high prevalence of Breast Cancer. J App Pharm, 4, 706-712.

24. Key TJ, Verkasalo PK, \& Banks E (2001). Epidemiology of breast cancer. Lancet oncol 2(3): 133-140.

25. Zahra F, Humayoun F, Yousaf $T \&$ Khan, NA (2013). Evaluation of risk factors for carcinoma breast in Pakistani women. J Fatima Jinnah Med Assoc 1: 34-38.

26. Moore MA, Ariyaratne $\mathrm{Y}$, Badar F, Bhurgri Y, Datta K, Mathew A \& Talukder MH (2010). Cancer epidemiology in South Asia-past, present and future. Asian Pac J Cancer P 11(Suppl 2), 49-66.

27. Logan GJ, Dabbs DJ, Lucas PC, Jankowitz RC, Brown DD, Clark BZ \& McAuliffe, PF (2015). Molecular drivers of lobular carcinoma in situ. Breast Cancer Research, 17(1), 76.

28. Asif HM, Sultana S, Akhtar N, Rehman, JU \& Rehman RU (2014). Prevalence, risk factors and disease knowledge of breast cancer in Pakistan. Asian Pac $J$ Cancer P 15(11): 4411-4416.

29. Hartmann LC, Sellers TA, Frost MH, Lingle WL, Degnim AC, Ghosh K \& 
Hillman DW (2005). Benign breast disease and the risk of breast cancer. New Engl J Med, 353(3): 229-237.

30. Eberl MM, Sunga AY, Farrell CD \& Mahoney MC (2005). Patients with a family history of cancer: identification and management. $J$ Am Board Fam Pract 18(3): 211-217.

31. Portenoy RK \& Ahmed E (2018). Cancer pain syndromes. Hematology/Oncology Clinics, 32(3): 371-386.

32. Beckles MA, Spiro SG, Colice GL \& Rudd RM (2003). Initial evaluation of the patient with lung cancer: symptoms, signs, laboratory tests, and paraneoplastic syndromes. Chest, 123(1): 97S-104S.

33. Heim E, Valach L \& Schaffner L (1997). Coping and psychosocial adaptation: longitudinal effects over time and stages in breast cancer. Psychosom Med 59(4), 408-418.

34. Segal R, Evans W, Johnson D, Smith J, Colletta S, Gayton J \& Reid R (2001). Structured exercise improves physical functioning in women with stages I and II breast cancer: results of a randomized controlled trial. J Clin Oncol, 19(3): 657665.

35. Strnad V, Ott OJ, Hildebrandt G, KauerDorner D, Knauerhase H, Major T \& Miguelez CG (2016). 5-year results of accelerated partial breast irradiation using sole interstitial multicatheter brachytherapy versus whole-breast irradiation with boost after breastconserving surgery for low-risk invasive and in-situ carcinoma of the female breast: a randomised, phase 3, noninferiority trial. Lancet 387(10015): 229238.

36. Leighl NB, Dent $S$, Clemons $M$, Vandenberg TA, Tozer R, Warr DG \& Dancey JE (2008). A Phase 2 study of perifosine in advanced or metastatic breast cancer. Breast Cancer Res $\mathrm{Tr}$ 108(1): 87-92.

37. Gianni L, Pienkowski T, Im YH, Roman L, Tseng LM, Liu MC \& Im, SA (2012). Efficacy and safety of neoadjuvant pertuzumab and trastuzumab in women with locally advanced, inflammatory, or early HER2-positive breast cancer (NeoSphere): a randomised multicentre, open-label, phase 2 trial. Lancet Oncol 13(1): 25-32.

38. Rosen EM, Fan S, Pestell RG \& Goldberg ID (2003). BRCA1 gene in breast cancer. Journal of cellular physiology, 196(1): 19-41.

39. Jabbir F, Irfan M, Mustafa G, Ahmad HI, \& Afzal G (2019). Bioinformatics Approaches to Explore the Phylogeny and Role of Brca1 in Breast Cancer. Crit Rev Eukar Gene (DOI: 10.1615).

40. Mehrgou A \& Akouchekian M (2016). The importance of BRCA1 and BRCA2 genes mutations in breast cancer development. M J IRI 30, 369.

41. Liede A, Karlan BY, \& Narod SA (2004). Cancer risks for male carriers of germline mutations in BRCA1 or BRCA2: a review of the literature. J Clin Oncol 22(4): 735-742.

42. Bondiau PY, Gal J, Chapellier C, Haudebourg J, Courdi A, Levy J \& Château Y (2019). Robotic Stereotactic Boost in Early Breast Cancer, a Phase 2 Trial. Int J Radiat Oncol 103(2): 374380.

43. De Siervi A, De Luca, P, Byun, JS, Di, LJ, Fufa T, Haggerty CM \& Gardner K (2010). Transcriptional autoregulation by BRCA1. Cancer Res 70(2): 532-542.

44. Domchek S, Postel-Vinay S, Im S, Park YH, Delord J, Italiano A \& Krebs M (2019). Abstract PD5-04: An open-label, phase II basket study of olaparib and durvalumab (MEDIOLA): Updated results in patients with germline BRCA- 
mutated (gBRCAm) metastatic breast cancer (MBC): AACR.

45. Tavtigian SV, Oefner PJ, Babikyan D, Hartmann A, Healey S, Le Calvez-Kelm F \& Forey N (2009). Rare, evolutionarily unlikely missense substitutions in ATM confer increased risk of breast cancer. Am J Hum Genet 85(4): 427-446.

46. Zhong Q, Peng HL, Zhao X, Zhang L \& Hwang WT (2014). Effects of BRCA1and BRCA2-related mutations on ovarian and breast cancer survival: a meta-analysis. Clin Cancer Res clincanres. 1816.2014.

47. Park B, Dowty JG, Ahn, C, Win AK, Kim SW, Lee MH \& Park SK (2015). Breast cancer risk for Korean women with germline mutations in BRCA1 and BRCA2. Breast Cancer Res Tr 152(3): 659-665.

48. Moatter T, Aban M, Khan S, Azam I \& Pervez S (2011). BRCA1 status in Pakistani breast cancer patients with moderate family history. $J$ Coll Physicians Surg Pak 21(11): 680.

49. Kotsopoulos J, Lubinski J, Salmena L, Lynch HT, Kim-Sing C, Foulkes WD \& Tung N (2012). Breastfeeding and the risk of breast cancer in BRCA1 and BRCA2 mutation carriers. Breast Cancer Res 14(2): R42.

50. Breast TN CI, Hunter D \& Consortium PCC (2005). A candidate gene approach to searching for low-penetrance breast and prostate cancer genes. Nat Rev Cancer 5(12): 977.

51. Ayub SG, Rasool S, Ayub T, Khan SN, Wani KA \& Andrabi KI (2014). Mutational analysis of the BRCA2 gene in breast carcinoma patients of Kashmiri descent. Mol med reports 9(2): 749-753.

52. Musolino A, Naldi N, Michiara M, Bella MA, Zanelli P, Bortesi B \& Ardizzoni A (2005). A breast cancer patient from Italy with germline mutations in both the
BRCA1 and BRCA2 genes. Breast Cancer Res Tr 91(2): 203-205.

53. Kuo WH, Chang YY, Lai LC, Tsai MH, Hsiao CK, Chang KJ, \& Chuang EY (2012). Molecular characteristics and metastasis predictor genes of triplenegative breast cancer: a clinical study of triple-negative breast carcinomas. PLoS One 7(9): e45831.

54. Aida H, Takakuwa K, Nagata H, Tsuneki I, Takano M, Tsuji S \& Takahashi K (1998). Clinical features of ovarian cancer in Japanese women with germline mutations of BRCA1. Clin Cancer Res 4(1): 235-240.

55. Lakhani SR, Manek S, Penault-Llorca, F, Flanagan A, Arnout L, Merrett S \& Klijn JG (2004). Pathology of ovarian cancers in BRCA1 and BRCA2 carriers. Clin Cancer Res 10(7), 2473-2481.

56. Rubin SC, Benjamin I, Behbakht K, Takahashi H, Morgan MA, LiVolsi VA \& Weber BL (1996). Clinical and pathological features of ovarian cancer in women with germ-line mutations of BRCA1. New Engl J Med 335(19): 1413-1416.

57. DeSantis CE, Ma, Gaudet MM, Newman LA, Miller KD, Goding Sauer A \& Siegel RL (2019). Breast cancer statistics. CA Cancer J Clin 2019.

58. Butt S, Harlid S, Borgquist, S, Ivarsson, M, Landberg, G, Dillner, J \& Manjer J (2012). Genetic predisposition, parity, age at first childbirth and risk for breast cancer. BMC res notes 5(1): 414.

59. Saygin C, Matei D, Majeti R, Reizes O \& Lathia JD (2018). Targeting cancer stemness in the clinic: from hype to hope. Cell Stem Cell.

60. Bashir MN (2015). Epidemiology of prostate cancer. Asian Pac J Cancer P 16(13), 5137-5141.

61. Nichols HB, Schoemaker MJ, Cai J, Xu J, Wright LB, Brook MN \& Bertrand KA (2019). Breast cancer risk after recent 
childbirth: a pooled analysis of 15 prospective studies. Ann Intern Med 170(1): 22-30.

62. Mahdavi M, Nassiri M, Kooshyar MM, Vakili-Azghandi M, Avan A, Sandry R \& Gopalan V (2019). Hereditary breast cancer; Genetic penetrance and current status with BRCA. J Cell Physiol 234(5): 5741-5750.

63. Bordoni A, Probst-Hensch, N, Mazzucchelli L \& Spitale A (2009). Assessment of breast cancer opportunistic screening by clinicalpathological indicators: a populationbased study. Brit J Cancer 101(11): 1925-1931.

64. Ruddy KJ, Gelber SI, Tamimi RM, Ginsburg ES, Schapira L, Come SE \& Partridge AH (2014). Prospective study of fertility concerns and preservation strategies in young women with breast cancer. J Clin Oncol 32(11): 1151-1156.

65. de Pedro M, Otero B \& Martín B (2015). Fertility preservation and breast cancer: a review. ecancermedicalscience, 9.

66. Armuand GM, Rodriguez-Wallberg, KA, Wettergren L, Ahlgren J, Enblad G, Höglund M \& Lampic C (2012). Sex differences in fertility-related information received by young adult cancer survivors. J Clin Oncol 30(17): 2147-2153.

67. Cummings P, Weiss NS, McKnight B \& Stanford JL (1997). Estimating the risk of breast cancer in relation to the interval since last term pregnancy. Epidemiology 8(5): 488-494.

68. Letourneau JM, Smith, JF, Ebbel EE, Craig A, Katz PP, Cedars MI \& Rosen MP (2012). Racial, socioeconomic, and demographic disparities in access to fertility preservation in young women diagnosed with cancer. Cancer 118(18): 4579-4588.

69. Kranick JA, Schaefer C, Rowell S, Desai M, Petrek JA, Hiatt RA \& Senie RT
(2010). Is pregnancy after breast cancer safe? Breast 16(4): 404-411.

70. Azim HA, Santoro L, Pavlidis N, Gelber S, Kroman N, Azim H \& Peccatori FA (2011). Safety of pregnancy following breast cancer diagnosis: a meta-analysis of 14 studies. Eur J Cancer 47(1): 74-83.

71. Easton DF. Ford D \& Bishop DT (1995). Breast and ovarian cancer incidence in BRCA1-mutation carriers. Breast Cancer Linkage Consortium. Am J Hum Genet 56(1): 265.

72. Maqsudur Rashid A, Ramalingam L, AlJawadi A, Moustaid-Moussa N \& Moussa H (2019). Low dose radiation, inflammation, cancer and chemoprevention. Int $J$ of Radiat Biol 95(4): 506-515.

73. Ford D, Easton D, Stratton M., Narod S, Goldgar D, Devilee P \& Chang-Claude J (1998). Genetic heterogeneity and penetrance analysis of the BRCA1 and BRCA2 genes in breast cancer families. Am J Hum Genet 62(3): 676-689.

74. Polyak K (2011). Heterogeneity in breast cancer. J clin investig 121(10): 3786-3788.

75. Liu G, Yang D, Sun Y, Shmulevich I, Xue F, Sood AK \& Zhang W (2012). Differing clinical impact of BRCA1 and BRCA2 mutations in serous ovarian cancer. Pharmacogenomics 13(13): 1523-1535.

76. Harbeck N, Salem M, Nitz U, Gluz O \& Liedtke C (2010). Personalized treatment of early-stage breast cancer: present concepts and future directions. Cancer Treat Rev 36(8): 584-594.

77. Raskob GE, van Es N, Verhamme P, Carrier M, Di Nisio M, Garcia D \& Mercuri MF (2018). Edoxaban for the treatment of cancer-associated venous thromboembolism. New Engl J Med 378(7): 615-624.

78. Byler S, Goldgar S, Heerboth S, Leary M, Housman G, Moulton K \& Sarkar S 
(2014). Genetic and epigenetic aspects of breast cancer progression and therapy. Anticancer Res 34(3): 1071-1077.

79. Dhankhar R, Vyas SP, Jain AK., Arora S, Rath G, \& Goyal AK (2010). Advances in novel drug delivery strategies for breast cancer therapy. Artifi Cell Blood Sub 38(5): 230-249.

80. Akram M \& Siddiqui S (2012). Breast cancer management: past, present and evolving. Indian J Cancer 49(3): 277.

81. Eroles P, Bosch A, Pérez-Fidalgo JA \& Lluch A (2012). Molecular biology in breast cancer: intrinsic subtypes and signaling pathways. Cancer Treat Rev 38(6) 698-707.
82. Wu J, Lu LY \& Yu X (2010). The role of BRCA1 in DNA damage response. Protein Cell 1(2): 117-123.

83. Rieder V, Salama M, Glöckner L, Muhr D, Berger A, Tea MK \& Weingartshofer $S$ (2016). Effect of lifestyle and reproductive factors on the onset of breast cancer in female BRCA 1 and 2 mutation carriers. Mol genet genom med 4(2): 172-177.

84. Roy R., Chun J \& Powell SN (2012). BRCA1 and BRCA2: different roles in a common pathway of genome protection. Nat Rev Cancer 12(1): 68-78.

85. Anjum RS (2013). Purification and characterization of proteins important for homologous recombination in eukaryotes. Univ Agri, Faisalabad. 